Józef Makarczyk, Prowincja litewsko-białoruska Zakonu Braci Mniejszych Konwentualnych w latach 1687-1845, Grodno 2012, (ss. 556)

Ks. Józef Makarczyk jest znaną postacią w gronie polskich badaczy Kościoła. Jego prace, poświęcone głównie dziejom zakonu franciszkańskiego na terenie prowincji litewsko-białoruskiej, były wielokrotnie przywoływane w literaturze naukowej. Opublikowany dorobek ks. Józefa Makarczyka stanowi znaczący wkład w badaniach nad historią życia zakonnego w nauce polskiej.

Książka ks. Józefa Makarczyka Prowincja litewsko-białoruska Zakonu Braci Mniejszych Konwentualnych w latach 1687-1845, Grodno 2012, (ss. 556) posiada nowatorski charakter. Praca składa się ze wstępu, pięciu obszernych rozdziałów, zakończenia, aneksów (ss. 50), bibliografii, wykazu skrótów, tabel i ilustracji oraz indeksów i streszczeń. Autor książki postawiał sobie za cel przedstawienie dziejów litewsko-białoruskiej prowincji franciszkanów od jej powstania po kasację w 1845 r. Zakres czasowy pracy nie budzi zastrzeżeń. Co prawda kasata klasztorów rzymskokatolickich, w tym i franciszkańskich, w Imperium Rosyjskim rozpoczęła się na szeroką skalę już po powstaniu listopadowym w 1832 r., ale słusznie autor zamyka swoje rozważanie na dacie likwidacji prowincji. Za słuszny należy uznać opis działalności franciszkanów po likwidacji prowincji, ich udział w powstaniu styczniowym i obsłudze duszpasterskiej po $1864 \mathrm{r}$.

We wstępnej części pracy autor wyjaśnia cele monografii, omawia stan badań nad dziejami prowincji litewskiej franciszkanów i wprowadza czytelnika do zasadniczych rozdziałów książki. Docenić należy wykorzystanie przez autora pracy obszernej literatury o różnej wartości poznawczej i o zróżnicowanej przydatności. Szkoda jednak, że w swych ustaleniach pominął kilka istotnych dla omawianej tematyki pozycji książkowych, jak: J. Flaga, Formacja i ksztatcenie duchowieństwa zakonnego w Rzeczypospolitej w XVII i XVIII wieku, Lublin 1998; Zakony $i$ klasztory w Europie Srodkowo-Wschodniej. X-XX wiek, pod red. H. Gapski, J. Kłoczowski, Lublin 1999, a zwłaszcza artykuły: Pála Attily Illésa o kasacie 
klasztorów franciszkańskich na Węgrzech; Mauricego Carmody o dziejach Zakonu Braci Mniejszych w Europie Srodkowej i Wschodniej w XIX wieku oraz Piotra Gacha o zakonach w Europie Środkowo-Wschodniej w latach 1773-1914. Mankamentem pracy jest nieuwzględnienie Istoriji Russkoj Cerkwi I. K. Smolicza. Jej najnowsze wydanie z krytycznymi komentarzami współczesnych historyków rosyjskich nie może być pominięte ${ }^{1}$. Przy ocenie wykorzystanej przez ks. Józefa Makarczyka literatury nasuwa się spostrzeżenie, że swoje sądy opiera głównie na podstawie ustaleń zawartych w literaturze i historiografii polskiej, niesłusznie pomijając cenne publikacje autorów rosyjskich i białoruskich. Ci ostatni dokonali wielu opracowań na temat dziejów miejscowości, w których znajdowały się franciszkańskie ośrodki zakonne.

Autor omawianej książki wykorzystał bogaty materiał archiwalny. Zapoznał się ze zbiorami przechowywanymi w państwowych i kościelnych archiwach Polski, Rosji, Litwy i Białorusi. Imponujący wykaz wykorzystanych materiałów rękopiśmiennych znajduje się $\mathrm{w}$ recenzowanej książce. $\mathrm{Z}$ obowiązku recenzenta należy zwrócić uwagę na niewykorzystanie przez autora książki kilka wydawnictw² ${ }^{2}$ które odnoszą się pośrednio do dziejów klasztorów franciszkańskich. Wydawnictwa te były wydawane po kasacie prowincji litewsko-białoruskiej, ale wielokrotnie poruszają problem byłych franciszkańskich ośrodków klasztornych, np. przy opisie poszczególnych miejscowości w guberni grodzieńskiej czy wileńskiej.

W interesującym pierwszym rozdziale publikacji autor omawia okoliczności powołania prowincji litewsko-białoruskiej franciszkanów, a następnie analizuje jej rozwój do końca XVIII wieku. Nie mam zastrzeżeń w materii prezentacji historii poszczególnych ośrodków zakonnych, jednak w kwestiach dotyczących historii omawianych miejscowości autor popełnia liczne pomyłki. Oto kilka przykładów: na str. 37 autor książki podaje, że po raz pierwszy Drohiczyn Poleski jest wzmiankowany w 1452 r., co jest ewidentną nieprawdą. Drohiczyn Poleski znany jest ze źródeł już w XIII wieku, w 1452 r. wszedł do powiatu pińskiego, wcześniej pozostawał we włości brzeskiej ${ }^{3}$; str. 43: kiedy podajemy podstawowe

1 I. K. Smolicz, Istorija Russkoj Cerkwi, ks. VIII, cz. 1-2, Moskwa 1997.

2 Pamiatnaja kniżka grodnienskoj guberni na 1864 god, Grodno 1863; Pamiatnaja kniżka grodnienskoj guberni na 1861 god, Grodno 1860; Pamiatnaja knizkka grodnienskoj guberni na 1871 god, Grodno 1871; Pamiatnaja kniżka grodnienskoj guberni na 1883 god, Grodno 1882; Pamiatnaja kniżka grodnienskoj guberni na 1884 god, Grodno 1883; Pamiatnaja knizkka Grodienskaj Gubernii na 1885 god, Grodno 1884; Pamiatnaja kniżka Grodienskaj Gubernii na 1887 god, Grodno 1886; Pamiatnaja kniżka Grodienskaj Gubernii na 1889 god, Grodno 1888; Pamiatnaja kniżka Grodienskaj Gubernii na 1890 god, Grodno 1889; Pamiatnaja kniżka Grodienskaj Gubernii na 1896 god, Grodno 1895.

3 F. Klimczuk, Oczerk driewniej i sriedniewiekowoj istorii Pinszcziny, „Histarycznaja Brama”, nr 1 (24), Pińsk 2009, s. 17-18; Gruszewskij A. S., Oczerk istorii Turowsko-Pińskogo kniażestwa w XI-XIII ww., Kijew 1901; tenże, Oczerk istorii Turowsko-Pińskogo kniażestwa w sostawie Litowsko-Russkago gosudarstwa XIV-XVI w., Kijew 1903. 
dane o rodzie książąt Holszańskich, nie można pominąć faktu, iż przedstawicielka tego rodu Zofia od 1422 r. była czwartą żoną Władysława Jagiełły; str. 54: Nowogródek nie dostał praw magdeburskich w 1444 r. W 1444 r. Kazimierz Jagiellończyk zwolnił miasto z licznych obciążeń podatkowych i zaliczył je do głównych miast Litwy. Cztery lata później zebrał się tutaj sejm litewski, aby doprowadzić do ugody skłóconą szlachtę polską i litewską podczas obrad w Lublinie. Prawa magdeburskie Nowogródek otrzymał dopiero w 1511 r. od Zygmunta Starego 4 ; str. 58: Pińsk ma znacznie „bogatsze” pochodzenie, aniżeli od roku 1097. Początkowo gród Pińsk (nazwa od rzeki Piny) ${ }^{5}$ znajdował się na terytorium wsi Horodziszcze, znajdującej się $12 \mathrm{~km}$ od obecnego miasta. Dopiero w XI wieku (około 1050 r.) gród ten został przeniesiony na miejsce nazwane Leszcz, przedmieście późniejszego Pińska ${ }^{6}$. Według wymienianego przez Wincentego Kadłubka i Macieja Stryjkowskiego - autora latopisu pińskiego Mitrofana, który żył w czasach Nestora, monaster leszczyński na przedmieściach Pińska został założony przez Włodzimierza Wielkiego. Według tego samego źródła książę Włodzimierz wysłał biskupa kijowskiego Leoncjusza do ziemi zamieszkałej przez Jaćwież celem założenia tam katedry, a sam wielokrotnie wyprawiał się w okolice Nowogródka, Pińska i Brześcia7; str. 71: Nie sposób zrozumieć, dlaczego autor, pisząc o Wilnie w czasach Giedymina i Olgierda, pomija trzech męczenników wileńskich Antoniego, Jana i Eustachego. Takich nieścisłości i pomyłek jest znacznie więcej. Uwaga ta dotyczy jednak spraw marginalnych z punktu widzenia poruszonego w książce zasadniczego tematu, jakim jest historia zakonu franciszkanów w prowincji litewsko-białoruskiej i w żadnym wypadku nie umniejsza wartości merytorycznej rozprawy. Po raz pierwszy mamy w jednym opracowaniu zgromadzone dzieje poszczególnych klasztorów franciszkańskich, oparte na solidnym materiale archiwalnym i najnowszej historiografii.

W rozdziale drugim książki, który został poświęcony działalności zewnętrznej klasztorów, Autor w sposób kompetentny dokonuje prezentacji różnorodnych form aktywności franciszkanów. Ks. J. Makarczyk analizuje działalność duszpasterską, pracę kaznodziejską, misyjną, propagowanie kultu maryjnego i świętych. Docenić należy ogromny wysiłek badawczy ks. J. Makarczyka w analizie tych zjawisk w odniesieniu do poszczególnych parafii. $\mathrm{Z}$ owego zarysowanego obrazu wynika duże zaangażowanie Braci Mniejszych Konwentualnych wśród wiernych nie tylko swoich parafii i miejscowości, w których klasztor się znajdował, ale i na terenie poszczególnych kustodii.

4 SGKP, t. VII, Warszawa 1886, s. 257.

5 P. Łysenko, Driewnij Pinsk: XI-XIII ww., Mińsk, 1997, s. 11.

6 F. Klimczuk, Oczerk driewniej i sriedniewiekowoj istorii Pinszcziny, „Histarycznaja Brama”, nr 1 (24), Pińsk 2009, s. 9, 11.

7 Wospominanije o driewniem prawosławii Zapadnoj Rusi, Moskwa 1867, s. 12-13; 15-16. 
Opis dziejów poszczególnych ośrodków franciszkańskich i ich zewnętrznej aktywności autor nie zawsze mógł należycie ukazać. Ograniczała badacza dostępność źródeł. Czasami mamy wrażenie, że ten brak nowych danych autor rozprawy rekompensuje cytatami ze źródeł, które w tym fragmencie pracy nie mają nic wspólnego z podnoszoną tematyką. Opisy parafii, ich inwentarze czy wyszczególnienie ksiąg kancelaryjnych, np. w parafii holszańskiej, wnoszą niewiele albo wcale do omówienia działalności duszpasterskiej czy misyjnej będących tam franciszkanów. Informacje takie znajdujemy chociażby w danych statystycznych dotyczących liczby osób przyjmujących komunię i liczby udzielonych sakramentów.

Zgadzam się ze stanowiskiem ks. J. Makarczyka o wielkiej roli kaznodziejstwa franciszkańskiego. Zakonnicy rzeczywiście często byli zapraszani do wygłoszenia kazań na odpustach, pogrzebach, ślubach i innych uroczystościach religijnych. Potwierdzeniem tego zjawiska są liczne księgi z kazaniami na różne okoliczności przechowywane w bibliotekach klasztornych. Oprócz wymogów edukacyjnych przy uzyskaniu zgody na prowadzenie działalności kaznodziejskiej podstawowe znaczenie miały postawy prawno-moralne. $\mathrm{Z}$ zestawienia ks. J. Makarczyka wynika, że głoszeniem kazań pozaklasztornych w prowincji litewsko-białoruskiej zajmowało się około $15 \%$ franciszkanów. Warto byłoby porównać procentowy udział w kaznodziejstwie zakonników z innych klasztorów łacińskich. Mało znanym zjawiskiem - poruszonym przez autora publikacji - było głoszenie kazań w synagogach żydowskich. Szkoda, że autor pracy szerzej nie napisał, w jaki sposób owo kaznodziejstwo odbywało się w praktyce.

Z uznaniem należy ocenić ustalenia grodzieńskiego duchownego i historyka przy omawianiu pomocy duszpasterskiej franciszkanów w parafiach diecezjalnych i w pełnieniu przez nich funkcji kapelanów dworskich. Zawarta w tym podrozdziale bogata faktografia wnosi wiele nowych elementów poznawczych. Relacja klasztor a darczyńca miała więc wymiar nie tylko materialny (donacja), ale nakładała na zakonników nowe obowiązki duszpasterskie wobec rodziny dworskiej. Ks. J. Makarczyk ukazuje liczbę i rolę mnichów - franciszkanów $\mathrm{w}$ pomocy duszpasterskiej w parafiach diecezjalnych. Postulatem badawczym wobec tego fragmentu staje się ukazanie wzajemnych relacji między zakonnikami a duchowieństwem diecezjalnym.

Za szczególnie interesujący należy uznać fragment pracy o propagowaniu przez franciszkanów prowincji litewsko-białoruskiej kultu maryjnego i świętych. Warto wziąć pod uwagę wezwania kościołów franciszkańskich. Szkoda, że problem ten nie został rozwinięty przez ks. J. Makarczyka. Duża liczba świątyń pod wezwaniem św. Antoniego Padewskiego, Niepokalanego Poczęcia NMP i Wniebowzięcia NMP wskazuje na promocję dwóch szczególnych świąt w Kościele rzymskokatolickim i rozwinięty kult św. Antoniego Padewskiego. Oba święta podkreślały katolicką naukę związaną z narodzeniem i śmiercią Matki 
Bożej na terenach wyznaniowo mieszanych. Kult św. Antoniego Padewskiego był z kolei przeciwwagą dla szczególnie popularnego w Kościele wschodnim kultu św. Antoniego Pieczerskiego. Podnoszony przez autora pracy rozwój kultu maryjnego i św. Franciszka wśród samych franciszkanów był zjawiskiem normalnym i wynikał z charakteru samego zakonu. Szkoda, że autor książki nie wykorzystał w tym rozdziale kilku ważnych dla tej tematyki opracowań: Mathiasa Niendorfa, Wielkie Księstwo Litewskie. Studia nad ksztattowaniem się narodu u progu epoki nowożytnej, Poznań 2011 (s. 205-236); B. R. Vitauskiené, Marijos Kulas. Paveikslai kaip vienas Marijas gerbimo LDK reiškiniu, Litetuvos Didžiosios Kunigaikštijos kultūra, Tyrinějimai Ir vaizadai, pod red. A. Ališauskas, L. Jovaiša, M. Paknys, E. Raila, Vilnius 2001; Kultura Wielkiego Księstwa Litewskiego. Analizy i obrazy, L. Jovaiša, M. Paknys, E. Raila, Kraków 2006, s. $268-282$.

Cały podrozdział poświęcony organizacjom i stowarzyszeniom kościelnym stworzonym przez franciszkanów został oparty na materiale archiwalnym. Znajdziemy w nim podstawowe informujące o tercjarstwie - organizacji skupiającej świeckich, bractwie Paska św. Franciszka z Asyżu, bractwie św. Antoniego z Padwy, bractwie św. Anny, Szkaplerza NMP, Serca Pana Jezusa, św. Iwony, Dobrej Śmierci, św. Kiliana, św. Mikołaja. Niestety, ograniczony zasób źródeł uniemożliwił autorowi pracy szersze omówienie charakteru działalności wymienionych organizacji kościelnych na terenie prowincji litewsko-białoruskiej. W przypadku działalności charytatywnej autor opisał ją głównie na podstawie zachowanych wizytacji. Nie mam zastrzeżeń do danych faktograficznych, ale w części opisowej wykorzystałbym ustalenia innych badaczy. Por. Charitas. Miłosierdzie i opieka społeczna $w$ ideologii, normach postępowania i praktyce społeczności wyznaniowych w Rzeczypospolitej XVI-XVIII wieku, pod red. U. Augustyniak i A. Karpińskiego, Warszawa 1999.

Trzeci rozdział omawianej książki został poświęcony wspólnocie klasztornej. Autor na podstawie reguł klasztornych, rozporządzeń prawno-kanonicznych i źródeł kościelnych, głównie wizytacji, omawia organizację życia zakonnego, wewnętrzne praktyki wspólnotowe, kapituły i konwokacje, wizytacje klasztorne i biblioteki. Ten ponad sześćdziesięciostronicowy rozdział oddaje ducha funkcjonowania zakonu Braci Mniejszych Konwentualnych w prowincji litewsko-białoruskiej. Poznajemy w nim życie wewnętrzne wspólnoty, obowiązki i funkcje mnichów, ich życie sakramentalne, modlitwy, praktyki pokutne, klauzulę zakonną. Ks. J. Makarczyk omawia różne rodzaje wizytacji klasztornych: prowincjalskie, kustoszowskie, generalne i biskupie. Dzięki tym wizytacjom możemy poznać życie wewnętrzne klasztoru, stan materialny i personalny zgromadzenia oraz organizacje okołowspólnotowe. Oceniając pozytywnie ten fragment pracy, z obowiązku recenzenta, zwracam uwagę na usterki metodologiczne. Autor umiejętnie prezentuje regułę klasztorną np. w sprawie praktyk pokutnych wziętych z reguły papieża Urbana VIII, ale jedynie w ograniczony sposób ukazuje, jak wyglądało 
jej stosowanie w praktyce zakonu franciszkańskiego na terenie prowincji litewsko-białoruskiej.

Kolejny ponad stustronicowy rozdział dotyczy postaw materialnych poszczególnych klasztorów. Zawarta w nim bogata faktografia daje podstawy do oceny stanu materialnego wspólnot oraz zawiera dane o ich fundatorach i kolatorach. Oparcie analizy problemu głównie o wizytacje (które zawierają informacje o zapisach fundacyjnych, testamentach) i nielicznych opracowaniach - to za mało, ażeby całościowo objąć zagadnienie. Autor powinien sięgnąć w tym wypadku do lustracji, inwentarzy poszczególnych dóbr i majętności, archiwów rodowych np. Chodkiewiczów czy Radziwiłłów, które pośrednio lub bezpośrednio ukazują nam donacje i zapisy na rzecz klasztorów. Uwaga taka nie jest istotna, albowiem przy tak obszernym ujęciu tematu autor książki i tak wykazał się dużą umiejętnością wydobywania informacji z dostępnych mu materiałów źródłowych. Nie rozumiem natomiast, dlaczego ks. J. Makarczyk po analizie stanu materialnego wszystkich klasztorów nie dokonał w zakończeniu rozdziału oceny ich stanu posiadania i nie porównał go z uposażeniem innych zgromadzeń zakonnych w tym czasie.

Rozdział piąty dotyczy kasaty klasztorów franciszkańskich i jej skutków. Autor omawia ukaz cara Mikołaja I z 1832 r. na podstawie którego zlikwidowano 29 klasztorów franciszkańskich w prowincji litewsko-białoruskiej. Wielkim osiągnięciem ks. J. Makarczyka jest nie tylko ukazanie stanu poszczególnych klasztorów przed ich zamknięciem, ale opis sytuacji po r. 1832. Los duchownych i obiektów klasztornych to druga odsłona kasacji klasztorów. Z owego opisu wynika, że najlepszy los spotkał budynki klasztorne, gdy trafiły one do duchowieństwa diecezjalnego. Inne zostały zniszczone bądź przemianowane na inne cele użyteczności publicznej.

Równie interesująca, oparta na materiale źródłowym, jest druga część tego rozdziału ukazująca losy klasztorów franciszkańskich po 1832 r. Mowa tu o ośrodkach zakonnych, które nie zostały zamknięte ukazem carskim. Z dziesięciu pozostałych ośrodków jedynie klasztor grodzieński funkcjonował po $1864 \mathrm{r}$. Klasztor grodzieński funkcjonował do 1918 r. jako swoiste więzienie dla kapłanów. Ten fragment książki posiada całkowicie nowatorski charakter i stanowi cenny wkład w poznanie dziejów zakonów w XIX wieku na dawnych ziemiach Rzeczypospolitej. Docenić należy wysiłki ks. J. Makarczyka w ukazaniu udziału karmelitów w powstaniu styczniowym i ich aktywność duszpasterską po $1864 \mathrm{r}$. Część biograficzną, ukazującą losy poszczególnych gwardianów i zakonników franciszkańskich, uznałbym za najmocniejszą część ocenianej publikacji.

$\mathrm{W}$ pracy znajdują się liczne błędy warsztatowe, a nawet gramatyczne. Nie rozumiem, dlaczego autor książki w niektórych przypisach nazwę archiwum lub jego skrót podaje w wersji cyrylickiej, a dalej w wersji łacińskiej. Brak konsekwencji jest też przy kolejności danych podanych w załącznikach, np. (przyp. 16 na str. 83 i na wielu innych stronach) autor podaje przypis w brzmieniu: РГИА, 
Akta wizytacji klasztoru pińskiego z 1820 r., s. 12-14, sygn. F. 822, op. 12, spr. 3393. Tymczasem przypis powinien być zapisany w następujący sposób: Akta wizytacji klasztoru pińskiego z 1820 r., RGIA, f. 822, op. 12, $\mathrm{nr} 3393$, k. 12-14 lub Akta wizytacji klasztoru pińskiego z 1820 r., РГИА, ф. 822, оп. 12, д. 3393, к. 12-14. Autor w licznych tabelach wstawia w tytule słowo ,ilość dworów, miejscowości, katolików” zamiast ich „liczba” (np. s. 107-110). To samo z danymi statystycznymi dotyczącymi liczby chrztów, małżeństw, etc. (np. s. 121), kaznodziejów (s. 129), uczniów (s. 197, 205).

Pomimo powyższych uwag, moja opinia o książce ks. Józefa Makarczyka jest w pełni pozytywna. Jej główną wartością jest przedstawienie dziejów litewsko-białoruskiej prowincji franciszkanów od jej powstania po kasację w $1845 \mathrm{r}$. $\mathrm{Z}$ tego zamierzenia autor pracy wywiązał się doskonale. Zwracam uwagę na połączenie w recenzowanej publikacji wielu elementów o charakterze historycznym, teologicznym i kulturowym. Ks. J. Makarczyk zmuszony był doskonale poznać historię, regułę zakonu franciszkańskiego oraz realia, w jakich owe wspólnoty funkcjonowały na terenie prowincji litewsko-białoruskiej. Jestem przekonany, że najnowsza publikacja ks. J. Makarczyka wzbudzi zainteresowanie nie tylko badaczy dziejów Kościoła i Grodzieńszczyźny, ale stanie się ważny wkładem w poznaniu dziejów dawnej Rzeczypospolitej.

Antoni Mironowicz

Wydział Historyczno-Socjologiczny

Uniwersytet w Białymstoku

\section{Andrzej Mania, Department of State 1789-1939. Pierwsze 150 lat udziału w polityce zagranicznej USA, Kraków, Wydawnic- two Uniwersytetu Jagiellońskiego, 2011, ss. 316.}

Niedawno ukazała się na rynku wydawniczym kolejna książka autorstwa Andrzeja Mani - znanego i zasłużonego amerykanisty związanego z Uniwersytetem Jagiellońskim, badającego tematykę historii i polityki Stanów Zjednoczonych Ameryki i współczesnych stosunków międzynarodowych. Autor jest twórcą licznych monografii i artykułów z wyżej wspomnianych zagadnień ${ }^{1}$ oraz wydał

\footnotetext{
1 Przykładowo można wymienić takie publikacje jak: A. Mania, Détente i polityka Stanów Zjednoczonych wobec Europy Wschodniej styczeń 1969 - styczeń 1981, Kraków 2003; idem, Polityka administracji Franklina D. Roosevelta wobec Zwiazku Radzieckiego w latach 1933-1939, Kraków 1987, idem, Polityka administracji Franklina D. Roosevelta wobec Zwiazku Radzieckiego w latach 1933-1939, Kraków 1982, idem, Ludzie i struktury: kształtowanie polityki zagranicznej i polityki bezpieczeństwa USA w latach 1969-1976, „Dzieje Najnowsze”, 2001, nr 1, s. 175-191, idem, Między niemożnościq a zaniechaniem: USA wobec Europy Wschodniej w okresie prezydentury Eisenhowera 1953-1956, „Zeszyty Naukowe Uniwersytetu Jagiellońskiego. Prace Historyczne”, 1997, z. 122 , s. $59-78$.
} 